\title{
PEMBUATAN LOGAM YTRIUM DENGAN PROSES METALOTERMIK
}

\author{
Preparation of Yttrium by Metallothermic Process
}

\author{
ISYATUN RODLIYAH dan SITI ROCHANI \\ Puslitbang Teknologi Mineral dan Batubara \\ Jalan Jenderal Sudirman 623 Bandung 40211 \\ Telp. (022) 6030483, Fax. (022) 6003373 \\ e-mail: isya@tekmira.esdm.go.id
}

\begin{abstract}
SARI
Monasit yang banyak ditemukan bersama dengan mineral kasiterit dan mineral zirkon, dapat diolah menjadi campuran logam tanah jarang oksida kemudian dipisahkan menjadi masing masing logam oksida yang selanjutnya dapat diproses menjadi logamnya. Logam tanah jarang ini banyak digunakan untuk bahan material maju. Dalam penelitian ini, ytrium oksida yang diektrak dari monasit diperoleh dari Pusat Sains dan Teknologi Akselerator-Badan Tenaga Atom Nasional (PSTA-BATAN) mempunyai kadar 73,53\%, dilarutkan dalam asam klorida dengan variasi konsentrasi dan waktu kemudian diendapkan dengan amonia klorida menjadi ytrium klorida. Ytrium klorida kemudian dilebur melalui proses peleburan metalometri menggunakan logam Ca atau $\mathrm{Mg}$ serta $\mathrm{NaCl}$ dan $\mathrm{CaCl}_{2}$ sebagai aditif, menghasilkan logam ytrium. Hasil percobaan menunjukkan bahwa pembetukan $\mathrm{YCl}_{3}$ diperoleh pada kondisi pelarutan $\mathrm{HCl} 0,4 \mathrm{~N}$ dengan waktu pelarutan 45 menit. Selanjutnya, peleburan dengan proses metalotermik, menggunakan reduktor $\mathrm{Mg}(1: 1)$ dengan aditif $\mathrm{NaCl}$ dan $\mathrm{CaCl}_{2}$, didapat logam yttrium. Hasil analisis SEM menunjukkan teridentifikasinya logam ytrium sebanyak 5,40 gram. Proses metalotermik ini dapat diterapkan untuk reduksi logam tanah jarang lainnya.
\end{abstract}

Kata Kunci: monasit, logam tanah jarang, ytrium, proses metalotermik.

\begin{abstract}
Monazite which is commonly associated with cassiterite and zircon minerals, can be processed into a rare metal oxide mixture. The mixture is then separated into several oxides which can further be processed into metal. The rare earth metals are widely used for advanced materials. In this study, yttrium oxide having a content of $73.53 \%$ was extracted from monazite obtained from Pusat Sains dan Teknologi Akselerator-Badan Tenaga Atom Nasional (PSTA-BATAN) and then it was dissolved in hydrochloric acid at various concentrations and time after precipitated with ammonia chloride to yttrium chloride. Yttrium chloride resulted was then smelted by metallometric process using $\mathrm{Ca}$ or $\mathrm{Mg}$ as well as $\mathrm{NaCl}$ and $\mathrm{CaCl}_{2}$ as additives, producing yttrium metal. The results of this study show that the highest formation of $\mathrm{YCl}_{3}$ was obtained in 0.4 $\mathrm{N} \mathrm{HCl}$ leaching conditions for 45 minutes dissolution time. Furthermore, with metalothermic smelting, yttrium metal was obtained by using reducing agent $\mathrm{Mg} \mathrm{(1:1)}$ and $\mathrm{NaCl}$ and $\mathrm{CaCl}_{2}$ as additives. Results of SEM analysis show that 5.40 grams of yttrium metal were identified. Yttrium metal extracted in this study shows that metallothermic process could be applied for other rare-earth metals reduction.
\end{abstract}

Keywords: monazite, rare earth metals, yttrium, metallothermic process. 


\section{PENDAHULUAN}

Di Indonesia mineral yang mengandung logam tanah jarang terdapat sebagai mineral ikutan pada komoditas utama terutama emas dan timah aluvial yang mempunyai peluang untuk diusahakan sebagai produk sampingan yang dapat memberikan nilai tambah mineral dengai nilai yang tinggi. Potensi endapan tersebut dapat dijumpai pada Jalur Timah Asia Tenggara yang mengandung sebagian besar sumber daya timah dunia melewati wilayah Indonesia mulai dari Kepulauan Karimun, Singkep sampai Bangka dan Belitung, merupakan potensi strategis yang dapat memberikan kontribusi besar kepada pembangunan nasional. Mineral logam tanah jarang yang paling bayak dijumpai di Indonesia adalah monasit dan senotim.

Monasit ((Ce,La,Y,Th)PO 3 ) merupakan senyawa fosfat logam tanah jarang yang mengandung $50-70 \%$ oksida logam tanah jarang (LTJ). Monasit umumnya diambil dari konsentrat yang merupakan hasil pengolahan dari endapan pada timah aluvial bersama dengan zirkon dan senotim. Monasit memiliki kandungan thorium yang cukup tinggi. Komposisi mineral tersebut dapat dilihat pada Tabel 1.

Tabel 1. Komposisi oksida dalam percontoh monasit Bangka (Soepriyanto dan Buchari, 2010)

\begin{tabular}{cccc}
\hline Oksida & Jumlah (\%) & Oksida & Jumlah (\%) \\
\hline $\mathrm{SiO}_{2}$ & 8,42 & $\mathrm{Gd}_{2} \mathrm{O}_{3}$ & 0,67 \\
$\mathrm{TiO}_{2}$ & 6,26 & $\mathrm{Yb}_{2} \mathrm{O}_{3}$ & 0,34 \\
$\mathrm{Al}_{2} \mathrm{O}_{3}$ & 1,78 & $\mathrm{Y}_{2} \mathrm{O}_{3}$ & 3,49 \\
$\mathrm{Fe}_{2} \mathrm{O}_{3}$ & 4,91 & $\mathrm{Nd}_{2} \mathrm{O}_{3}$ & 6,72 \\
$\mathrm{P}_{2} \mathrm{O}_{5}$ & 13,59 & $\mathrm{Dy}_{2} \mathrm{O}_{3}$ & 0,53 \\
$\mathrm{ZrO}_{2}$ & 12,93 & $\mathrm{La}_{2} \mathrm{O}_{3}$ & 6,99 \\
$\mathrm{HfO}_{2}$ & 0,33 & $\mathrm{Sm}_{2} \mathrm{O}_{3}$ & 0,92 \\
$\mathrm{Cr}_{2} \mathrm{O}_{3}$ & 0,28 & $\mathrm{CeO}$ & 16,62 \\
$\mathrm{ThO}_{2}$ & 3,17 & $\mathrm{SnO}$ & 7,81 \\
$\mathrm{Er}_{2} \mathrm{O}_{3}$ & 0,39 & Lain-lain & 3,85 \\
\hline
\end{tabular}

Monasit setelah diolah baik menjadi oksidanya maupun logamnya, memegang peranan yang sangat penting dalam kebutuhan material berteknologi tinggi seperti superkonduktor, laser, optik elektronik, aplikasi LED dan iPAD, gelas dan keramik (Koltun dan Tharumarajah, 2014). Kebutuhan industri oksida LTJ dunia lebih dari 90\% disuplai oleh Tiongkok (Lee et al., 2016). Sejak tahun 2004 Tiongkok mengurangi ekspor LTJ untuk memasok kebutuhan dalam negerinya, sedangkan kebutuhan terhadap oksida LTJ di dunia dari tahun ke tahun semakin meningkat, sehingga suplai LTJ dari sumber-sumber negara lain sangat dibutuhkan termasuk Indonesia karena memiliki potensi LTJ yang sangat besar.

Penelitian mengenai pengolahan logam tanah jarang sudah dilakukan oleh beberapa instansi di Indonesia diantaranya oleh Badan Tenaga Atom Nasional (BATAN). PSTA (Pusat Sains dan Teknologi Akselerator) - BATAN Yogyakarta telah melakukan penelitian ekstraksi logam tanah jarang dari mineral monasit dan senotim Bangka dengan metode asam hingga memperoleh oksida logam LTJ berupa $\mathrm{Ce}_{2} \mathrm{O}_{3}$ dengan kadar 99,98\%, dan $\mathrm{Y}_{2} \mathrm{O}_{3}, \mathrm{La}_{2} \mathrm{O}_{3}, \mathrm{Nd}_{2} \mathrm{O}_{3}$ dengan kadar $>80 \%$ (Purwani dan Suyanti, 2011). Di samping itu, Pusat Teknologi Bahan Galian Nuklir (PTBGN)-BATAN Jakarta telah melakukan ekstraksi logam tanah jarang dari mineral monasit dan senotim Bangka dengan metode alkali/basa, dan diperoleh campuran logam tanah jarang oksida (RE-OH) dengan kadar 85,6\%. Dengan kondisi penelitian LTJ di Indonesia ini, maka masih diperlukan penelitian lanjutan terkait pengolahan LTJ di Indonesia untuk dapat memisahkan semua unsur yang termasuk dalam golongan Lantanida hingga sampai pada tahap perolehan logamnya.

Logam-logam tanah jarang dapat dipisahkan dengan mereduksi oksidanya menjadi logam dengan kemurnian hampir 95\% tergantung dari pengotornya. Salah satu metode untuk mereduksi oksida-LTJ dapat dilakukan melalui Proses metalotermik yang dapat dibagi menjadi dua proses, yaitu:

- Reduksi RE-F3 dengan logam Ca (calciothermic process).

- Reduksi RE-O2 dengan logam Ca.

Proses metalotermik ini memiliki kelemahan yaitu: suasana proses non-oksidasi dan membutuhkan energi yang tinggi. Kelebihannya, perolehan logam yang dihasilkan $>90 \%$. Proses metalotermik yang sedang dikembangkan saat ini adalah Ames Process (Ames Laboratory, 2016) yang dikembangkan di Amerika. Ames Process 
ditujukan untuk membuat logam tanah jarang dengan kemurnian yang tinggi dan mendapatkan uranium untuk Proyek Manhattan melalui reduksi metalotermik dari garam-logam menggunakan logam alkali tanah.

$2 \mathrm{RF}_{3}+3 \mathrm{Ca} \rightarrow 2 \mathrm{R}+3 \mathrm{CaF}_{2}$

Dalam proses ini, tanah jarang flourida $\left(\mathrm{RF}_{3}\right)$ direduksi dengan logam $\mathrm{Ca}$ menghasilkan logam tanah jarang dan terak kalsium flourida. $\mathrm{RF}_{3}$ dihasilkan dengan mereaksikan tanah jarang oksida $\left(\mathrm{R}_{2} \mathrm{O}_{3}\right)$ dengan asam flourida (HF) sesuai dengan reaksi di bawah ini:

$\mathrm{R}_{2} \mathrm{O}_{3}+6 \mathrm{HF} \rightarrow 2 \mathrm{RF}_{3}+3 \mathrm{H}_{2} \mathrm{O}$

Selain itu, Proses Ames juga mencakup reduksi langsung dari oksida tanah jarang dengan lantanum untuk empat logam tanah jarang yang memiliki tekanan uap yang sangat tinggi yaitu; Sm, Eu, Tm, dan Yb.

$\mathrm{R}_{2} \mathrm{O}_{3}+2 \mathrm{La} \rightarrow \mathrm{La}_{2} \mathrm{O}_{3}+2 \mathrm{R}(\mathrm{g})$

Reduksi logam tanah jarang yang memiliki titik leleh tinggi seperti yttrium (Y), dilakukan dengan logam kalsium dari bentuk floridanya. Selanjutnya proses vacuum casting untuk menghilangkan pengotor yang mudah menguap dan sublimasi untuk menghilangkan spesi yang tidak menguap (Riedemann, 2011).

Penelitian reduksi logam tanah jarang dengan proses metalotermik sudah dilakukan oleh beberapa peneliti. Salah satu grup peneliti yang juga telah mereduksi oksida logam tanah jarang menjadi logam dengan proses metalotermik diantaranya: (Bose dkk. (1985), melakukan penelitian pembuatan paduan LTJSi-Fe menggunakan proses metalotermik dengan mereduksi campuran LTJ-oksida dengan campuran Fe-Si dan reduktor aluminium serta aditif $\mathrm{CaO}-\mathrm{MgO}$ atau $\mathrm{CaOCaF}_{2}$ untuk mencegah hilangnya logam tanah jarang yang mungkin lari ke terak. Peleburan dilakukan dengan kapasitas $5 \mathrm{~kg}$ paduan per proses pada tanur induksi dengan temperatur $1500-1550^{\circ} \mathrm{C}$. Produkta paduan LTJ-Si-Fe mengandung 50\% logam tanah jarang dengan perolehan lebih dari $80 \%$. Sedangkan Yilmaz (2007), telah meneliti pembuatan tanah jarang fero silikon dengan proses metalothermik dari pre konsentrat basnasit menggunakan alumunium dan ferosilikon dilebur dalam tungku induksi yang menghasilkan tanah jarang ferosilikon dengan kadar 39,3 \% tanah jarang, 37,5 \% silikon, $19,3 \%$ besi dan 3,9 \% aluminium dengan perolehan $57,7 \%$ logam tanah jarang.

Penelitian untuk meningkatkan kadar logam yang dihasilkan selanjutnya telah banyak dilakukan, tercatat Laboratory Ames yang aktif melakukan penelitian reduksi metalotermik dengan umpan LTJ-florida yang direduksi dengan kalsium untuk menghasilkan logam dengan kemurnian $>90 \%$ (Kumari $d k k$., 2015).

Reduksi metalotermik LTJ-oksida juga dilakukan khususnya untuk Gd, Tb, Dy, dan Y dengan reduktor Al. Penambahan $\mathrm{Mg}$ dan $\mathrm{Zn}$ dapat menurunkan suhu proses karena menghasilkan paduan dengan logam tanah jarang yang memiliki titik leleh rendah. Elemen paduan dapat dihilangkan dengan distilasi menghasilkan logam tanah jarang murni (Habashi, 2013).

Reduksi metalotermik juga telah dikembangkan oleh Anderson, 2015 yaitu melalui tahapan LTJ-klorida yang dilakukan dengan klorinasi langsung menggunakan gas klorin serta penggunaan karbon sebagai reduktornya pada suhu $700^{\circ} \mathrm{C}$. LTJ-klorida yang dihasilkan selanjutnya direduksi metalotermik menghasilkan kemurnian logam $>90 \%$.

Makalah ini bertujuan membahas pembuatan logam ytrium dari ytrium oksida melalui pembentukan ytrium klorida, dengan proses metalotermik. Penelitian dilakukan di Puslitbang Teknologi Mineral dan Batubara dengan percontoh ytrium oksida dari PTBGNBATAN yang telah mengekstraknya dari monasit.

\section{METODE}

Bahan baku untuk proses reduksi berupa ytrium oksida diperoleh dari PSTA-BATAN dikarakterisasi dengan melakukan analisis kimia dan fisika menggunakan ICP dan SEM untuk mengetahui komposisi oksida logam tanah jarang.

Dalam pembuatan logam ytrium, tahapan pertama adalah pembuatan ytrium klorida dari 
ytrium oksida melalui pelarutan dalam asam klorida. Parameter yang digunakan dalam proses pelarutan ini adalah konsentrasi pelarut $(0,1 ; 0,2 ; 0,3 ; 0,4 ; 0,5 ; 1 ; 1,5 ; 2,0 ; 3,0 \mathrm{~N})$ dan waktu pelarutan $(15,30,45,60,75$, dan 90 menit). Setelah proses pelarutan, dilakukan pengendapan dengan ammonium klorida untuk mendapatkan endapan yttrium klorida. Parameter tetap pada percobaan ini adalah suhu proses $30^{\circ} \mathrm{C}$ pada saat penambahan ammonium klorida (filtrat), berat sampel awal 20 gram dan persen padatan $30 \%$.

Endapan ytrium klorida yang dihasilkan selanjutnya dilakukan reduksi metalotermik untuk memperoleh logam ytrium (Y). Parameter untuk percobaan reduksi adalah jenis reduktor (Ca dan $\mathrm{Mg}$ ), jumlah reduktor (1x dan 2x stoikiometri), jenis umpan ( $\mathrm{Y}$ oksida dan Y-klorida) dan jenis aditifnya $\left(\mathrm{CaCl}_{2}\right.$ dan $\left.\mathrm{NaCl}\right)$. Diagram alir proses untuk memperoleh logam ytrium dapat dilihat pada Gambar 1.

\section{HASIL DAN PEMBAHASAN}

Komposisi kimia ytrium oksida yang diperoleh dapat dilihat pada Tabel 2. Bubuk ytrium oksida berwarna kekuningan (Gambar 2), mengandung 73,53 \% $\mathrm{Y}$ dalam $\mathrm{Y}_{2} \mathrm{O}_{3}$ dan logam tanah jarang lainnya serta masih terdeteksi logam logam lainnya dalam jumlah yang sedikit.

Proses pemisahan logam dari senyawanya atau yang lebih dikenal dengan istilah reduksi mengikuti reaksi:

$M X_{n}+i R=M+i R X_{(n / /}$

$M$ adalah logam yang dihasilkan; $X$ adalah oksigen, klorin, atau florin; dan $\mathrm{R}$ adalah pereduksi yang biasanya hidrogen, karbon atau logam lain seperti Li, Ca, Al, K, Na dan Mg. Pemilihan pereduksi yang tepat dapat ditentukan dengan melihat pembentukan energi bebas standarnya $\left(\Delta \mathrm{G}^{0}\right)$. Reaksi reduksi dapat terjadi apabila perbedaan $\Delta G^{0} M X_{n}$ dengan $\Delta \mathrm{G}^{0} \quad \mathrm{RX}_{(\mathrm{n} / \mathrm{i})}$ adalah $<0$ (negatif). Persamaan tersebut dapat ditulis (Gupta dan Krishnamurthy, 2005; Krishnamurthy dan Gupta, 2015)

$\mathrm{i} \Delta \mathrm{G}^{0} R X_{(n / i)}-M X_{n}<0$
Tabel 2. Hasil analisis kimia percontoh ytrium oksida

\begin{tabular}{ccc}
\hline No & LTJ-Oksida & $\begin{array}{c}\text { Kadar LTJ-Oksida } \\
\text { dalam } \mathrm{Y}_{2} \mathrm{O}_{3}(\%)\end{array}$ \\
\hline 1 & $\mathrm{Y}_{2} \mathrm{O}_{3}$ & 73,53 \\
2 & $\mathrm{La}_{2} \mathrm{O}_{3}$ & 0,86 \\
3 & $\mathrm{CeO}_{2}$ & 1,00 \\
4 & $\mathrm{Pr}_{6} \mathrm{O}_{11}$ & 0,19 \\
5 & $\mathrm{Nd}_{2} \mathrm{O}_{3}$ & 0,71 \\
6 & $\mathrm{Sm}_{2} \mathrm{O}_{3}$ & 0,22 \\
7 & $\mathrm{Eu}_{2} \mathrm{O}_{3}$ & - \\
8 & $\mathrm{Gd}_{2} \mathrm{O}_{3}$ & 4,63 \\
9 & $\mathrm{~Tb}_{4} \mathrm{O}_{7}$ & - \\
10 & $\mathrm{Dy}_{2} \mathrm{O}_{3}$ & 5,24 \\
11 & $\mathrm{Er}_{2} \mathrm{O}_{3}$ & 4,62 \\
12 & $\mathrm{Tm}_{2} \mathrm{O}_{3}$ & 0,31 \\
13 & $\mathrm{Al}_{2} \mathrm{O}_{3}$ & 0,12 \\
14 & $\mathrm{CaO}_{12}$ & 0,15 \\
15 & $\mathrm{~K}_{2} \mathrm{O}$ & 0,023 \\
16 & $\mathrm{TiO}_{2}$ & 0,028 \\
17 & $\mathrm{PbO}_{12}$ & 0,007 \\
18 & $\mathrm{LOI}$ & 7,00 \\
\hline
\end{tabular}

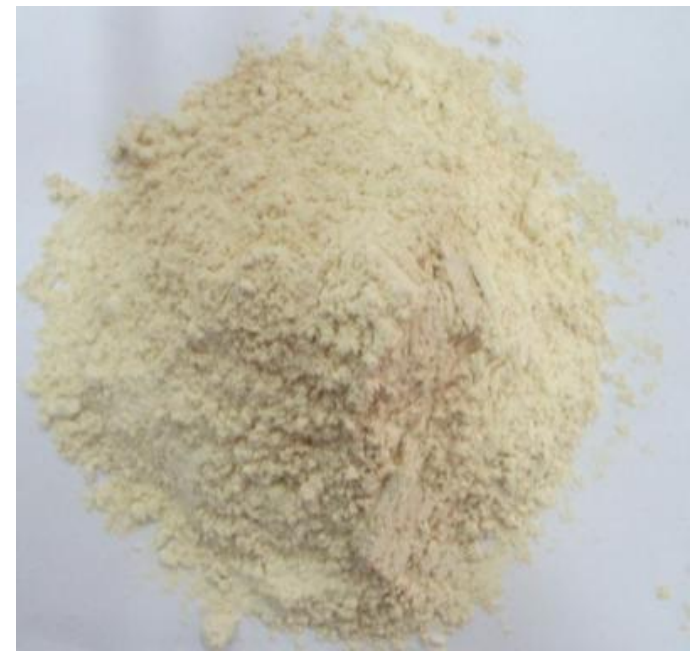

Gambar 2. Bubuk ytrium oksida

Proses reduksi untuk melepaskan logam dan senyawanya serta pembentukan senyawa RX bergantung juga terhadap suhu proses reduksi. Berikut disajikan grafik $\Delta \mathrm{G}^{0}$ untuk beberapa logam tanah jarang dan logam -oksida, florida, -klorida terhadap suhu yang dapat dilihat pada Gambar 3, 4, dan 5.

Dari Gambar 3, 4, dan 5 terlihat bahwa ytrium oksida memiliki $\Delta \mathrm{G}^{0}$ yang lebih negatif dibandingkan dengan $\Delta \mathrm{G}^{0}$ dari pereduksi seperti $\mathrm{CaO}, \mathrm{MgO}, \mathrm{Na}_{2} \mathrm{O}, \mathrm{Al}_{2} \mathrm{O}_{3}$ dan $\mathrm{Na}_{2} \mathrm{O}$ sehingga reduksi logam ytrium (Y) dalam 
bentuk oksida akan sulit untuk didapatkan (Gambar 3). Namun, ketika dalam bentuk ytrium klorida $\left(\mathrm{YCl}_{3}\right)$ akan mudah untuk menjadi logamnya ( $\mathrm{Y}$ ) dengan reduktor $\mathrm{K}, \mathrm{Ca}$, dan Li (Gambar 4). Sehingga ytrium oksida yang sudah diperoleh dari PSTA-BATAN direaksikan dengan asam klorida menjadi ytrium klorida.

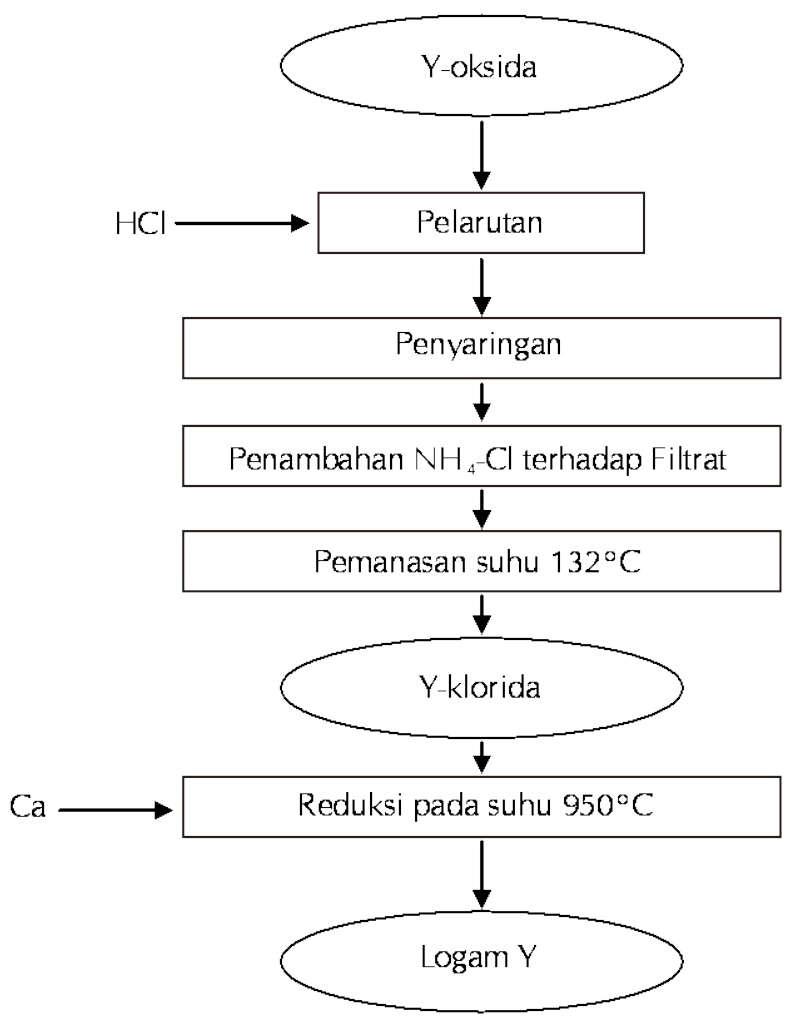

Gambar 1. Diagram alir proses untuk memperoleh logam yttrium

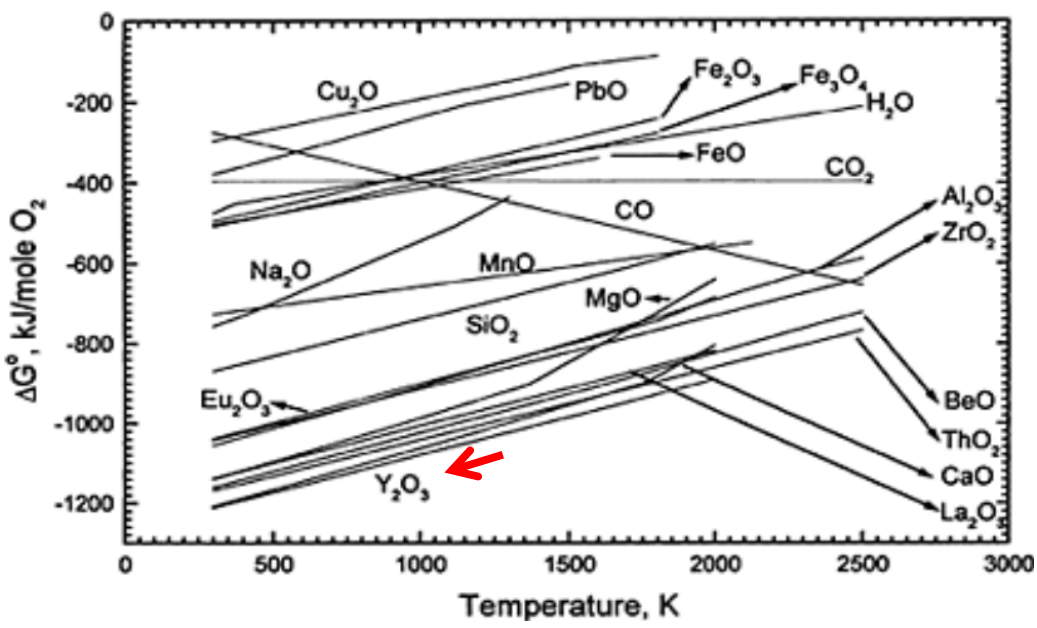

Gambar 3. Grafik energi bebas LTJ- dan logam- oksida terhadap suhu (Krishnamurthy dan Gupta, 2015) 


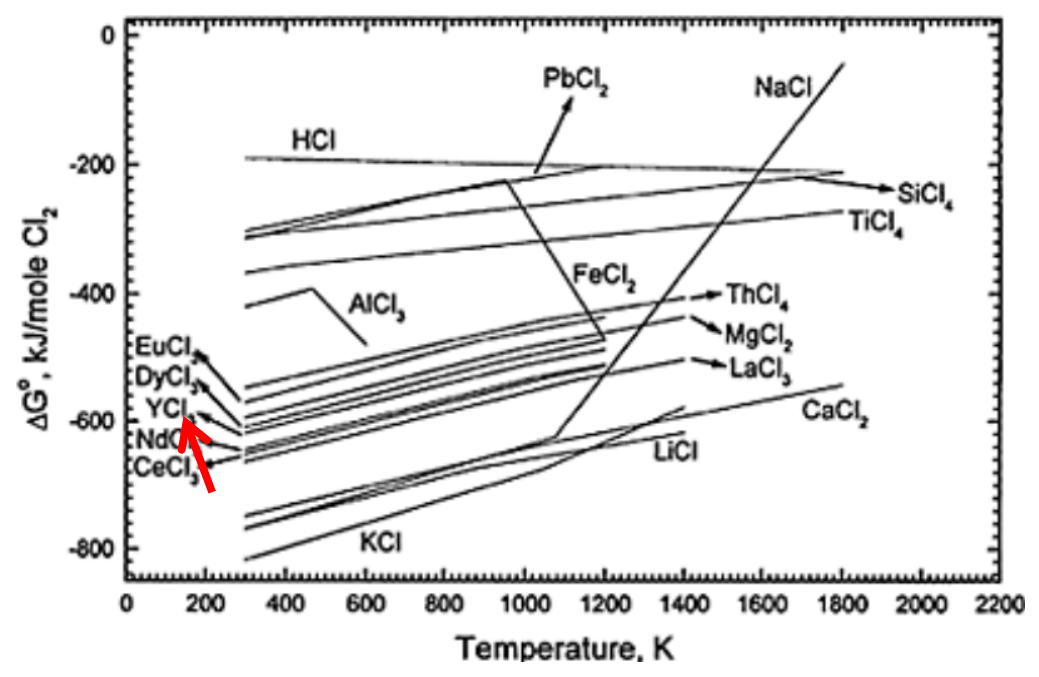

Gambar 4. Grafik energi bebas LTJ- dan logam- klorida terhadap suhu (Krishnamurthy dan Gupta, 2015))

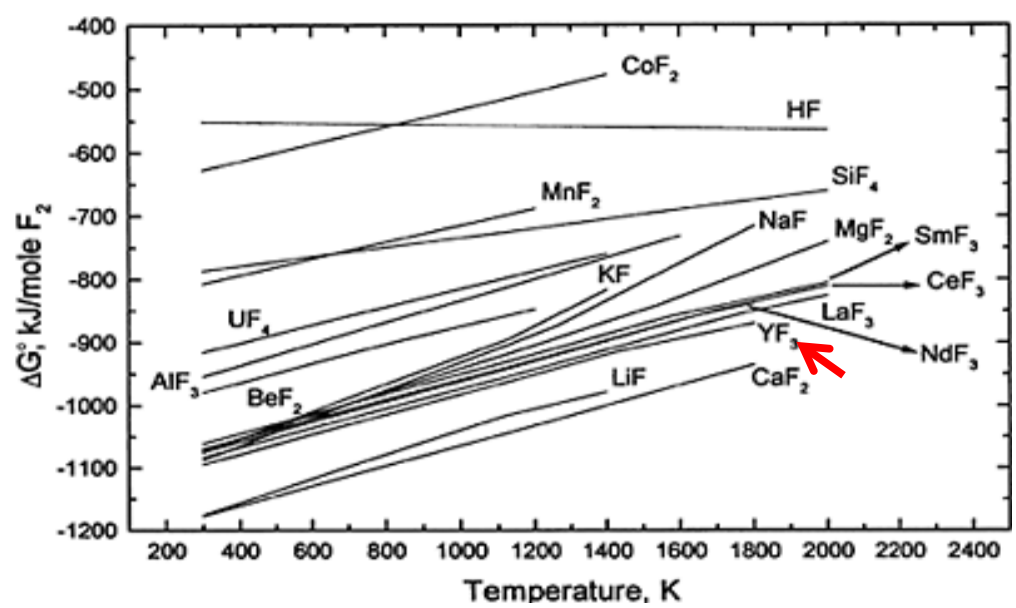

Gambar 5. Grafik energi bebas LTJ- dan logam- flourida terhadap suhu (Krishnamurthy dan Gupta, 2015)

Produk yang dihasilkan dengan variasi konsentrasi dapat dilihat pada Tabel 3, sedangkan komposisi kimianya berdasarkan analisis XRF dapat dilihat pada Tabel 4.

Berdasarkan data analisis Tabel 4 dan Gambar 6 terlihat bahwa \% kadar logam tanah jarang dari ytrium oksida pada variasi konsentrasi paling optimal ditunjukkan oleh konsentrasi asam klorida $0,4 \mathrm{~N}$.

Gambar 6 menunjukkan bahwa \% kadar logam tanah jarang dari ytrium yang tertinggi diperoleh pada saat digunakan konsentrasi asam klorida $0,4 \mathrm{~N}$ dengan persen logam tanah jarang dari ytrium total $5,41 \%$. Hasil analisis
XRD untuk konsentrasi asam klorida 0,4 N ditunjukkan pada Gambar 7.

Hasil analisis XRD pada pelarutan yttrium oksida menggunakan asam klorida 0,4 N (Gambar 7) menunjukkan bahwa komposisi senyawa yang paling dominan adalah ammonium klorida $\left(\mathrm{NH}_{4} \mathrm{Cl}\right)$. Diharapkan dari percobaan ini yang dominan terbentuk adalah yttrium klorida. Hal ini dapat terjadi karena yttrium yang terlarut dalam asam klorida sangat sedikit yaitu 5,41\%. Analisis XRD hanya dilakukan pada pelarutan asam klorida 0,4 N karena pada pelarutan tersebut menghasilkan $\%$ ekstraksi untuk ytrrium yang paling tinggi. Reaksi yang terjadi pada saat pelarutan yttrium 
oksida dengan asam klorida adalah seperti pada reaksi (5):

$\mathrm{Y}_{2} \mathrm{O}_{3}+6 \mathrm{HCl} \rightarrow 2 \mathrm{YCl}_{3}+3 \mathrm{H}_{2} \mathrm{O}$

Sementara itu, hasil percobaan dengan variasi waktu dapat dilihat pada Tabel 5 dan 6 serta Gambar 8. Terlihat bahwa \% kadar logam tanah jarang dari ytrium oksida untuk variasi waktu yang paling optimal adalah pada 45 menit dengan persen logam tanah jarang dari ytrium oksida total 8,62 \% dengan persen ekstraksi 93,2\%.

Setelah diperoleh produk ytrium klorida selanjutnya dilakukan percobaan pembuatan logam ytrium dengan mereduksi ytrium klorida menggunakan furnace (tungku reduksi) $1200^{\circ} \mathrm{C}$, selama 3 jam menggunakan reduktor Ca dan Mg. Selain itu dilakukan percobaan untuk mempelajari terbentuknya logam ytrium dengan menggunakan umpan dari ytrium oksida dan ytrium klorida. Proses reduksi dilakukan dengan menambahkan aditif $\mathrm{CaCl}_{2}$ dan $\mathrm{NaCl}$ yang berfungsi melindungi cairan logam agar tidak terjadi proses oksidasi kembali.

Pada penelitian ini, dipelajari juga proses pembuatan logam ytrium langsung dari ytrium oksida tanpa ytrium klorida sehingga dapat dibandingkan pembuatan logam ytrium dari ytrium oksida dan ytrium klorida dan dapat diketahui kondisi mana yang lebih baik.
Tabel 3. Berat produk dengan variasi konsentrasi

\begin{tabular}{cccc}
\hline \multirow{2}{*}{ No } & Konsentrasi & \multicolumn{2}{c}{ Massa (gram) } \\
\cline { 3 - 4 } & $\mathbf{( N )}$ & Filtrat & Residu \\
\hline 1 & 0,1 & 3,43 & 8,54 \\
2 & 0,2 & 3,46 & 8,25 \\
3 & 0,3 & 3,40 & 9,09 \\
4 & 0,4 & 3,76 & 9,07 \\
5 & 0,5 & 0,52 & 11,5 \\
6 & 1 & 20,99 & 47,67 \\
7 & 1,5 & - & 11,5 \\
8 & 2 & - & 9,89 \\
9 & 3 & - & 7,96 \\
\hline
\end{tabular}

Tabel 4. Kadar LTJ dalam filtrat dengan variasi konsentrasi

\begin{tabular}{llcccc}
\hline \multirow{2}{*}{ No } & \multirow{2}{*}{ LTJ } & \multicolumn{4}{c}{ Kadar LTJ (\%) } \\
\cline { 3 - 6 } & & $0,1 \mathrm{~N}$ & $0,2 \mathrm{~N}$ & $0,3 \mathrm{~N}$ & $0,4 \mathrm{~N}$ \\
\hline 1 & $\mathrm{Y}$ & 2,06 & 3,62 & 3,07 & 5,41 \\
2 & $\mathrm{La}$ & 0,49 & 0,18 & 0,49 & 0,57 \\
3 & $\mathrm{Ce}$ & 0,002 & 0,013 & 0,001 & 0,049 \\
4 & $\mathrm{Pr}$ & 0,021 & 0,011 & 0,022 & 0,031 \\
5 & $\mathrm{Nd}$ & 0,084 & 0,034 & 0,091 & 0,12 \\
6 & $\mathrm{Sm}$ & 0,005 & 0,001 & 0,007 & 0,007 \\
7 & $\mathrm{Eu}$ & 0,001 & $\mathrm{Tt}$ & 0,003 & 0,006 \\
8 & $\mathrm{Gd}$ & 0,28 & 0,17 & 0,34 & 0,43 \\
9 & $\mathrm{~Tb}$ & $\mathrm{Tt}$ & $\mathrm{Tt}$ & $\mathrm{Tt}$ & $\mathrm{Tt}$ \\
10 & $\mathrm{Dy}$ & 0,39 & 0,24 & 0,49 & 0,64 \\
11 & $\mathrm{Er}$ & 0,23 & 0,14 & 0,27 & 0,36 \\
12 & $\mathrm{Yb}$ & $\mathrm{Tt}$ & $\mathrm{Tt}$ & $\mathrm{Tt}$ & $\mathrm{Tt}$ \\
13 & $\mathrm{Lu}$ & 0,013 & 0,008 & 0,016 & 0,022 \\
\hline
\end{tabular}

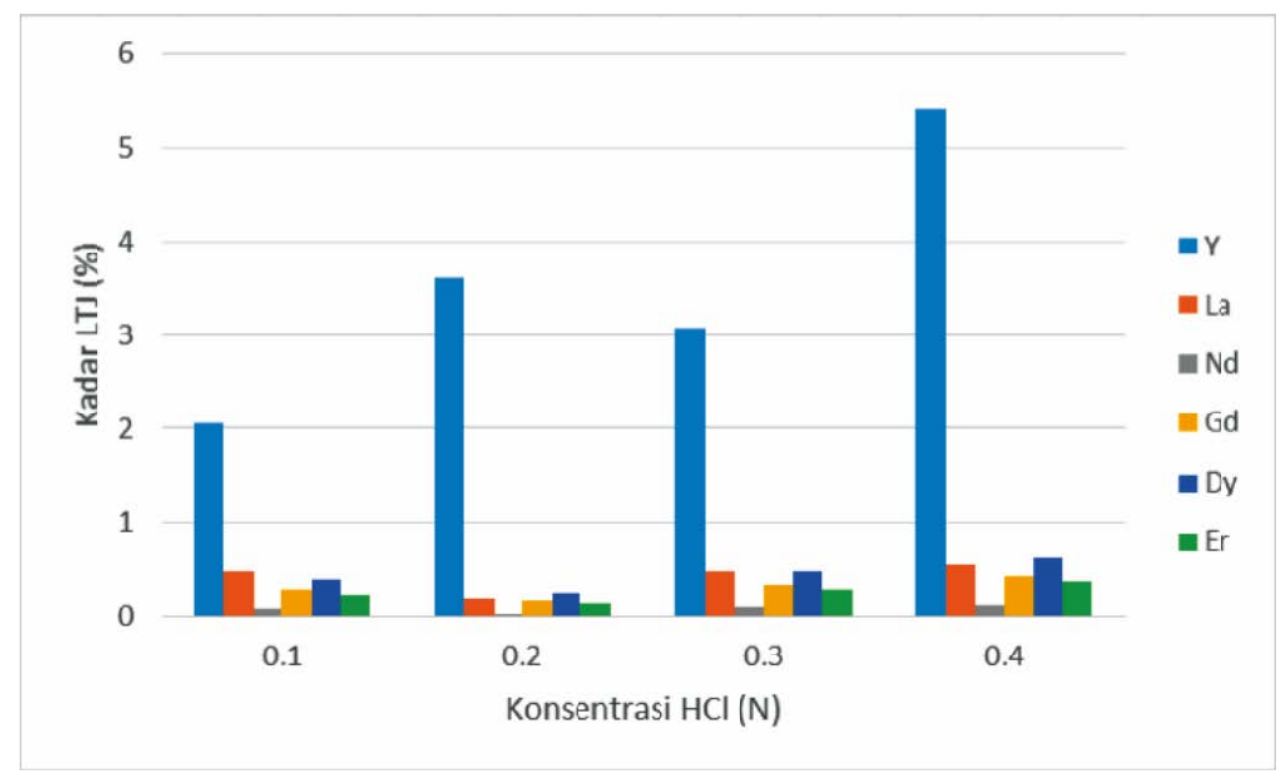

Gambar 6. Grafik kadar LTJ vs LTJ untuk berbagai konsentrasi asam klorida 


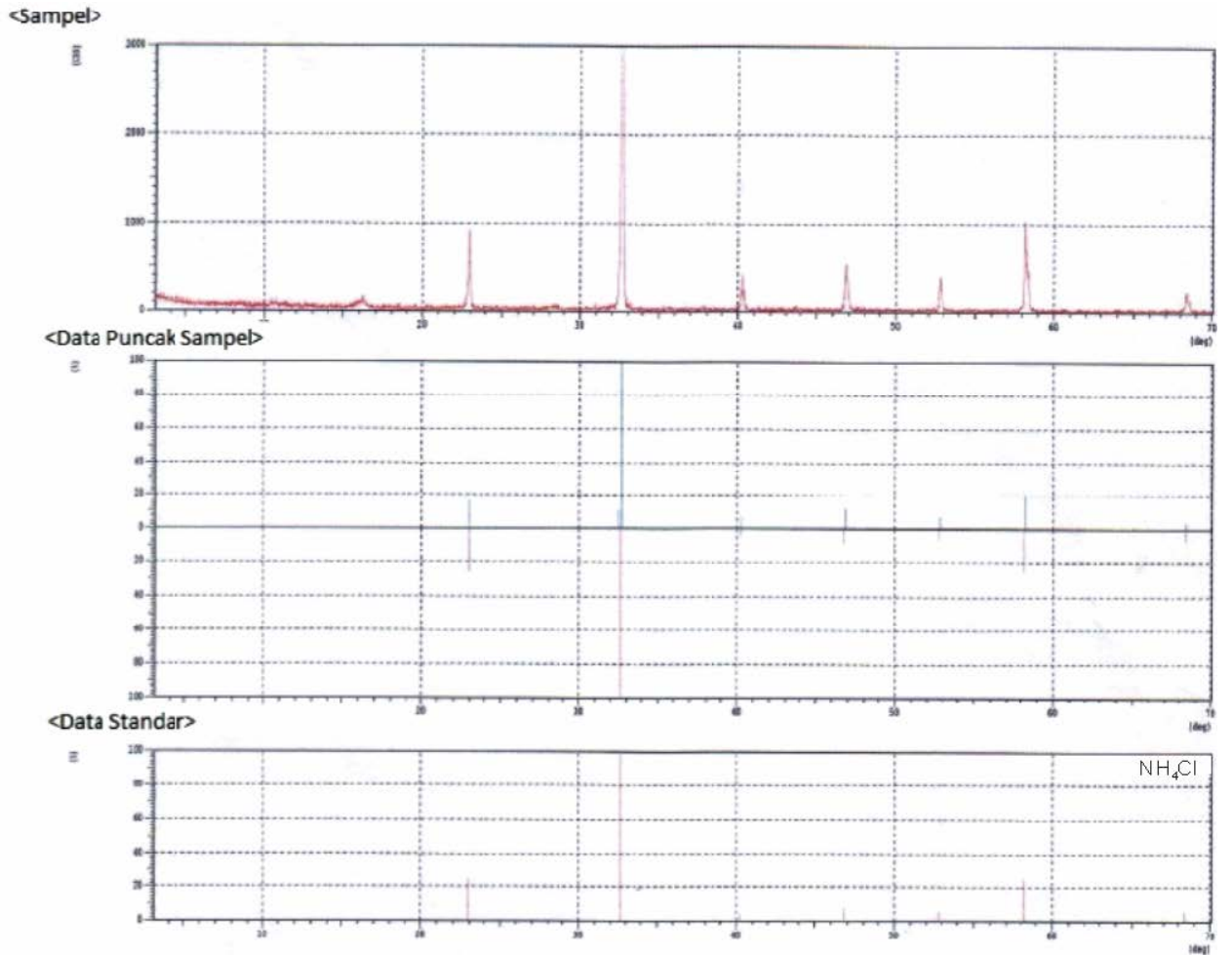

Gambar 7. Hasil analisis XRD pada konsentrasi asam klorida 0,4N

Tabel 5. Produk dengan variasi waktu pelarutan

\begin{tabular}{cccc}
\hline \multirow{2}{*}{ No } & \multirow{2}{*}{ Waktu (menit) } & \multicolumn{2}{c}{ Massa (gram) } \\
\cline { 3 - 4 } & & Filtrat & Residu \\
\hline 1 & 15 & 2,44 & 13,52 \\
2 & 30 & 2,31 & 16,67 \\
3 & 45 & 2,52 & 13,93 \\
4 & 60 & 3,76 & 9,09 \\
5 & 75 & 2,38 & 13,00 \\
6 & 90 & 2,56 & 13,51 \\
\hline
\end{tabular}

Tabel 6. Kadar LTJ dalam filtrat dengan variasi waktu pelarutan

\begin{tabular}{llcccccc}
\hline \multirow{2}{*}{ No } & \multirow{2}{*}{ LTJ } & \multicolumn{7}{c}{ Kadar LTJ $(\%)$} \\
\cline { 2 - 7 } & & 15 menit & 30 menit & 45 menit & 60 menit & 75 menit & 90 menit \\
\hline 1 & $\mathrm{Y}$ & 6,23 & 5,77 & 8,62 & 5,41 & 8,39 & 7,39 \\
2 & $\mathrm{La}$ & 0,83 & 0,44 & 1,17 & 0,57 & 1,08 & 0,76 \\
3 & $\mathrm{Ce}$ & $\mathrm{tt}$ & $\mathrm{Tt}$ & $\mathrm{Tt}$ & 0,049 & $\mathrm{Tt}$ & $\mathrm{Tt}$ \\
4 & $\mathrm{Pr}$ & 0,026 & 0,014 & 0,041 & 0,031 & 0,031 & 0,024 \\
5 & $\mathrm{Nd}$ & 0,13 & 0,11 & 0,26 & 0,12 & 0,17 & 0,18 \\
6 & $\mathrm{Sm}$ & 0,019 & 0,014 & 0,048 & 0,007 & 0,029 & 0,027 \\
7 & $\mathrm{Eu}$ & $\mathrm{tt}$ & $\mathrm{Tt}$ & $\mathrm{Tt}$ & 0,006 & $\mathrm{Tt}$ & $\mathrm{Tt}$ \\
8 & $\mathrm{Gd}$ & 0,57 & 0,45 & 1,13 & 0,43 & 0,70 & 0,79 \\
9 & $\mathrm{~Tb}$ & $\mathrm{tt}$ & $\mathrm{Tt}$ & $\mathrm{Tt}$ & $\mathrm{Tt}$ & $\mathrm{Tt}$ & $\mathrm{Tt}$ \\
10 & $\mathrm{Dy}$ & 0,48 & 0,39 & 0,93 & 0,64 & 0,56 & 0,65 \\
11 & $\mathrm{Er}$ & 0,68 & 0,49 & 1,18 & 0,36 & 0.79 & 0,80 \\
12 & $\mathrm{Yb}$ & 0.36 & 0,27 & 0,51 & $\mathrm{Tt}$ & 0,38 & 0,34 \\
13 & $\mathrm{Lu}$ & 0,083 & 0,070 & 0,15 & 0,022 & 0,096 & 0,098 \\
\hline
\end{tabular}




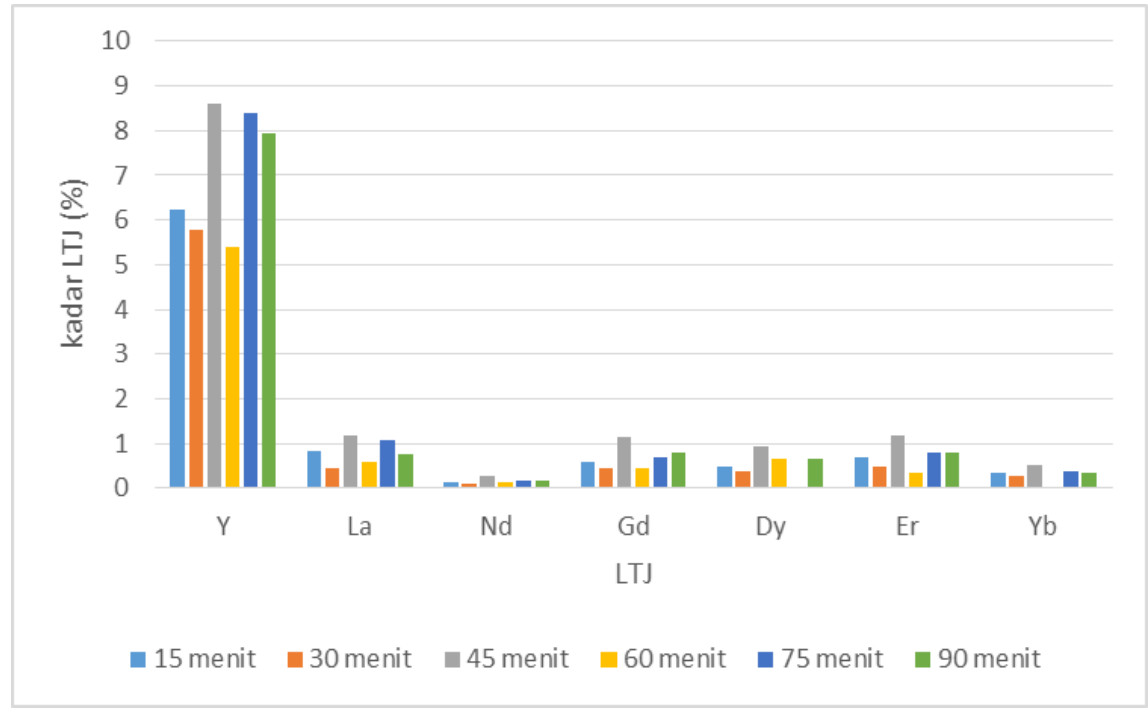

Gambar 8. Grafik waktu terhadap kadar LTJ (\%)

Persamaan reaksi dari proses reduksi antara $\mathrm{Y}_{2} \mathrm{O}_{3}$ dan $\mathrm{YCl}_{3}$ dengan reduktor $\mathrm{Mg}$ dan $\mathrm{Ca}$ dapat dituliskan sebagai berikut :

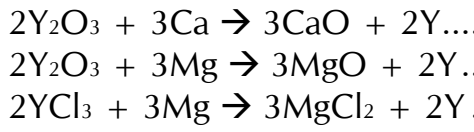

Hasil proses reduksi dengan suhu tinggi $1200^{\circ} \mathrm{C}$ yang berupa terak dan logam ditunjukkan pada Tabel 7. Terlihat bahwa yang menunjukkan terbentuknya logam $Y$ adalah dengan menggunakan umpan yttrium klorida dan reduktor $\mathrm{Mg}$ serta penambahan fluks $\mathrm{NaCl}$ dan $\mathrm{CaCl}_{2}$. Sedangkan dengan kondisi yang hampir sama hanya berbeda jumlah reduktornya, yang dihasilkan masih berupa sponge. Hal tersebut disebabkan pada saat proses reduksi suasana non-oksidatifnya tidak terkondisikan dengan baik, masih terdapat oksigen pada tungku.

Percobaan pertama dilakukan dengan mereduksi ytrium oksida menggunakan reduktor Ca tanpa penambahan aditif. Hasil analisa SEM pada proses reduksi ytrium oksida dengan menggunakan reduktor $\mathrm{Ca}$ dapat dilihat pada Gambar 9.

Gambar 9 menunjukkan belum terbentuknya logam ytrium. Material penyusun terdiri atas material terang (putih) dan kelabu. Kalsium
$(52,49 \%)$ dominan dan terpetakan dengan baik pada material kelabu sedangkan klor $(\mathrm{Cl})$ yang berasosiasi dengan Ca. Ytrium (20,41\%) merupakan penyusun material terang dan terpetakan dengan baik.

Percobaan selanjutnya adalah dengan mereduksi ytrium oksida menggunakan reduktor $\mathrm{Ca}$ (1:1) dan menambahkan aditif $\mathrm{NaCl}$ terhadap berat ytrium oksida pada umpan. Hasil analisa SEM pada proses reduksi ytrium oksida menggunakan reduktor $\mathrm{Ca}(1: 1)$ dan aditif $\mathrm{NaCl}$ dapat dilihat dari Gambar 10 .

Gambar 10 menunjukkan belum terbentuk logam ytrium. Material gelap mempunyai karakter menyudut dan melembar dengan unsur penyusun kalsium (45,12\%). Material terang umumnya membutir dengan penyusun ytrium $(29,03 \%)$. Kenampakkan pada fotomikrograf, material dengan komposisi ytrium terletak di atas material kalsium.

Percobaan selanjutnya adalah dengan mereduksi ytrium oksida menggunakan oksidator Ca dan menambahkan jumlah aditif pada umpan yaitu (1:2) dengan berat ytrium oksida. Hasil analisis SEM pada proses reduksi ytrium oksida dengan menggunakan reduktor Ca (1:2) dan aditif $\mathrm{NaCl}$ dapat dilihat pada Gambar 11. 
Tabel 7. Hasil berat terak dan logam ytrium proses reduksi

\begin{tabular}{clc}
\hline No & \multicolumn{1}{c}{ Komposisi Umpan Proses Reduksi } & $\begin{array}{c}\text { Hasil Berat Terak dan } \\
\text { Logam }\end{array}$ \\
\hline 1 & $\mathrm{Y}_{2} \mathrm{O}_{3}+$ reduktom $($ gram $)$ \\
2 & $\mathrm{Y}_{2} \mathrm{O}_{3}+$ reduktor $\mathrm{Ca}(1: 1)+$ aditif $\mathrm{NaCl}$ & $\mathrm{Tt}$ \\
3 & $\mathrm{Y}_{2} \mathrm{O}_{3}+$ reduktor $\mathrm{Ca}(1: 2)+$ aditif $\mathrm{NaCl}$ & $\mathrm{Tt}$ \\
4 & $\mathrm{Y}_{2} \mathrm{O}_{3}+$ reduktor $\mathrm{Mg}(1: 1)+$ aditif $\mathrm{NaCl}$ & $\mathrm{Tt}$ \\
5 & $\mathrm{Y}_{2} \mathrm{O}_{3}+$ reduktor $\mathrm{Mg}(1: 2)+$ aditif $\mathrm{NaCl}$ & $\mathrm{Tt}$ \\
6 & {$\left[\mathrm{Y}_{2} \mathrm{O}_{3}+\right.$ reduktor $\left.\mathrm{Mg}(1: 1)\right]+$ aditif $\mathrm{NaCl}+\mathrm{CaCl}_{2}$} & $\mathrm{Tt}$ \\
7 & {$\left[\mathrm{Y}_{2} \mathrm{O}_{3}+\right.$ reduktor $\left.\mathrm{Mg}(1: 2)\right]+$ aditif $\mathrm{NaCl}+\mathrm{CaCl}_{2}$} & $\mathrm{Tt}$ \\
8 & {$\left[\mathrm{YCl}_{3}+\right.$ reduktor $\left.\mathrm{Mg}(1: 1)\right]+$ aditif $\mathrm{NaCl}+\mathrm{CaCl}_{2}$} & $\mathrm{Tt}$ \\
9 & {$\left[\mathrm{YCl}_{3}+\right.$ reduktor $\left.\mathrm{Mg}(1: 2)\right]+$ aditif $\mathrm{NaCl}+\mathrm{CaCl}_{2}$} & 5,40 \\
\hline
\end{tabular}

Keterangan tt: tidak terbentuk

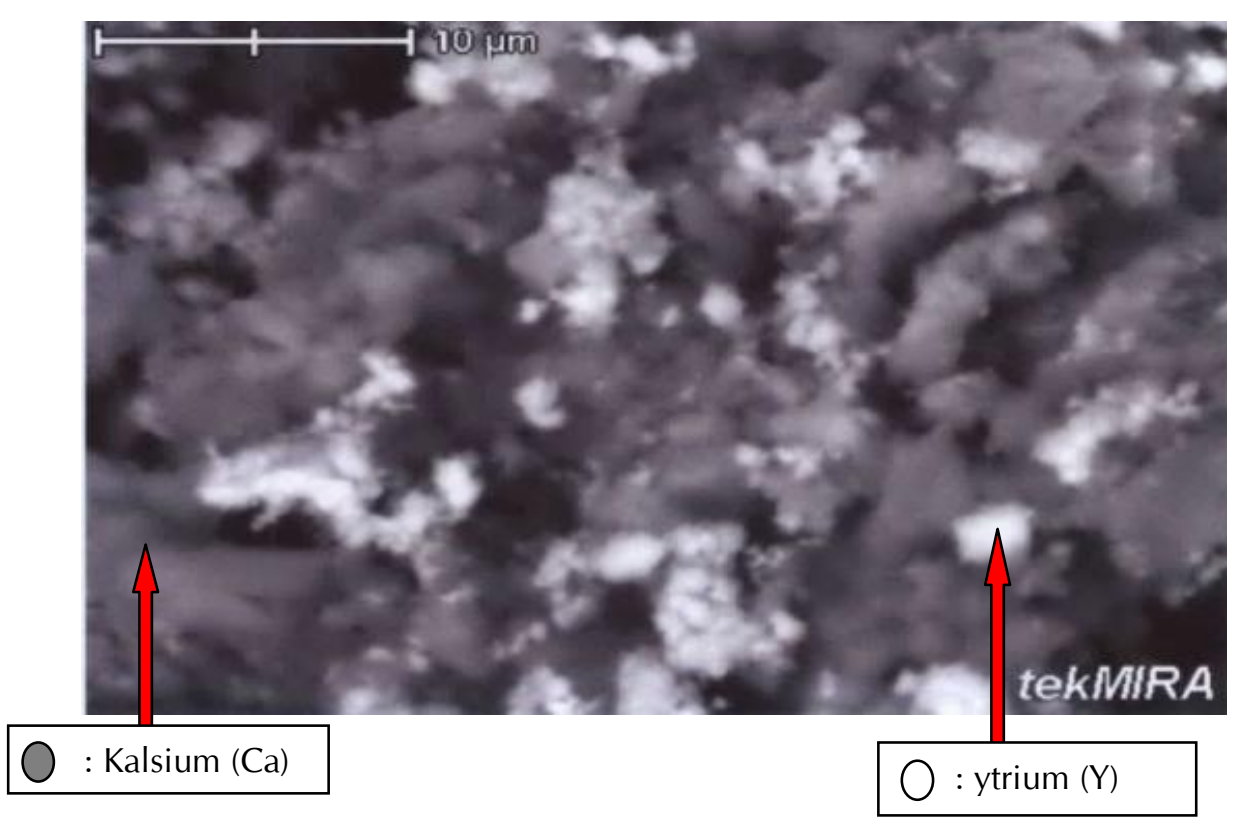

Gambar 9. Hasil analisis SEM reduksi ytrium oksida dengan reduktor Ca

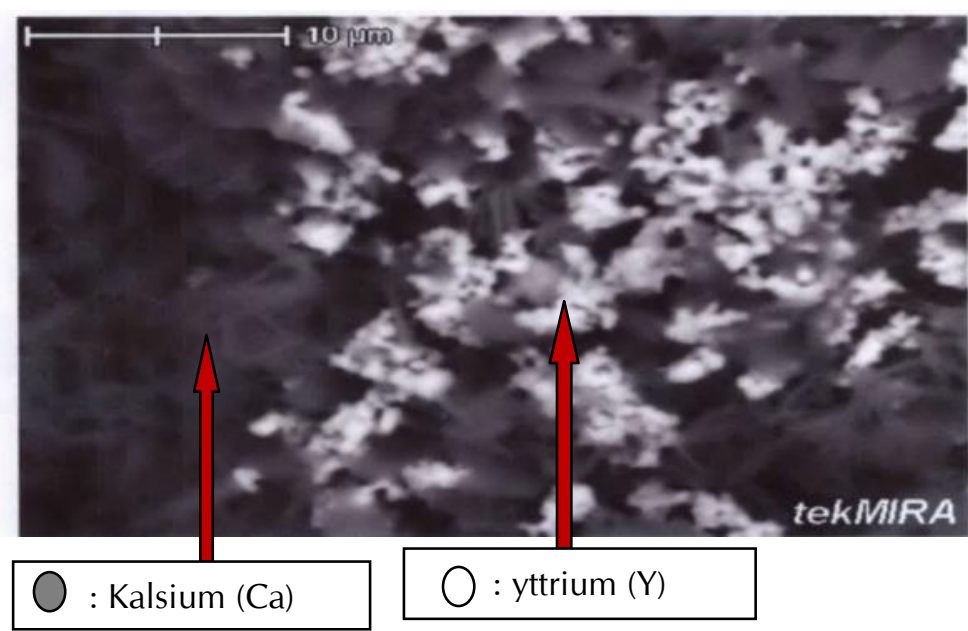

Gambar 10. Hasil analisis SEM reduksi ytrium oksida dengan reduktor $\mathrm{Ca}$ (1:1) dan aditif $\mathrm{NaCl}$ 


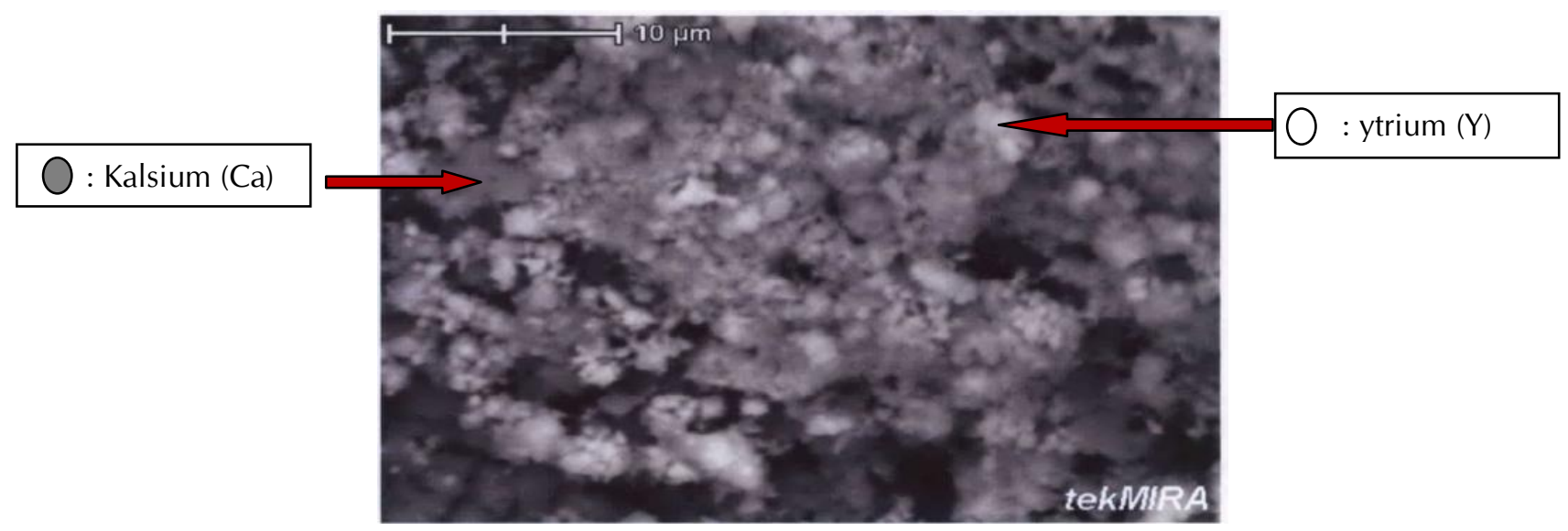

Gambar 11. Hasil analisis SEM reduksi ytrium oksida dengan reduktor Ca dan aditif $\mathrm{NaCl}(1: 2)$

Gambar 11 menunjukkan belum terbentuknya logam ytrium dan terdeteksinya tiga unsur yaitu kalsium (reduktor), ytrium, dan klor (aditif) serta Ca dominan pada spesimen $(49,24 \%)$. Ytrium terdeteksi pada hampir seluruh area deteksi walaupun pemetaannya kurang sempurna, diperkirakan memerlukan waktu yang lebih lama untuk memetakan ytrium agar terlihat lebih baik. Secara samar, $\mathrm{Cl}(1,64 \%)$ terlihat berasosiasi dengan material berbasis ytrium. Hasil proses masih berupa ytrium oksida.

Percobaan selanjutnya adalah dengan menggantikan reduktor $\mathrm{Ca}$ dengan $\mathrm{Mg}$ dan tetap menggunakan aditif $\mathrm{NaCl}$. Hasil analisis SEM pada proses reduksi ytrium oksida menggunakan reduktor $\mathrm{Mg}(1: 1)$ dan aditif $\mathrm{NaCl}$ dapat dilihat pada Gambar 12 .
Berdasarkan hasil Gambar 12 tersebut, nampak bahwa logam belum terbentuk. Secara individu, material-material tersebut terlihat sarang, mungkin mengalami korosi. Magnesium (1,30\%) terpetakan dengan baik di bagian kanan atas dan tengah area deteksi. Ytrium (38,79\%), osmium $(12,56 \%)$, dysprosium $(3,91 \%)$ dan tembaga $(1,95 \%)$ terdapat pada material yang sama. Y dan Os terpetakan dengan baik sedangkan Dy dan Cu terpetakan secara samar. Individu-individu penyusun ini terlihat mengelompok.

Percobaan selanjutnya adalah dengan mereduksi ytrium oksida dengan menambahkan jumlah aditif $\mathrm{NaCl}$ sedangkan reduktornya tetap yaitu Mg. Hasil analisis SEM pada proses reduksi dari ytrium oksida dengan menggunakan reduktor $\mathrm{Mg}(1: 2)$ dan aditif $\mathrm{NaCl}$ dapat dilihat pada Gambar 13 .

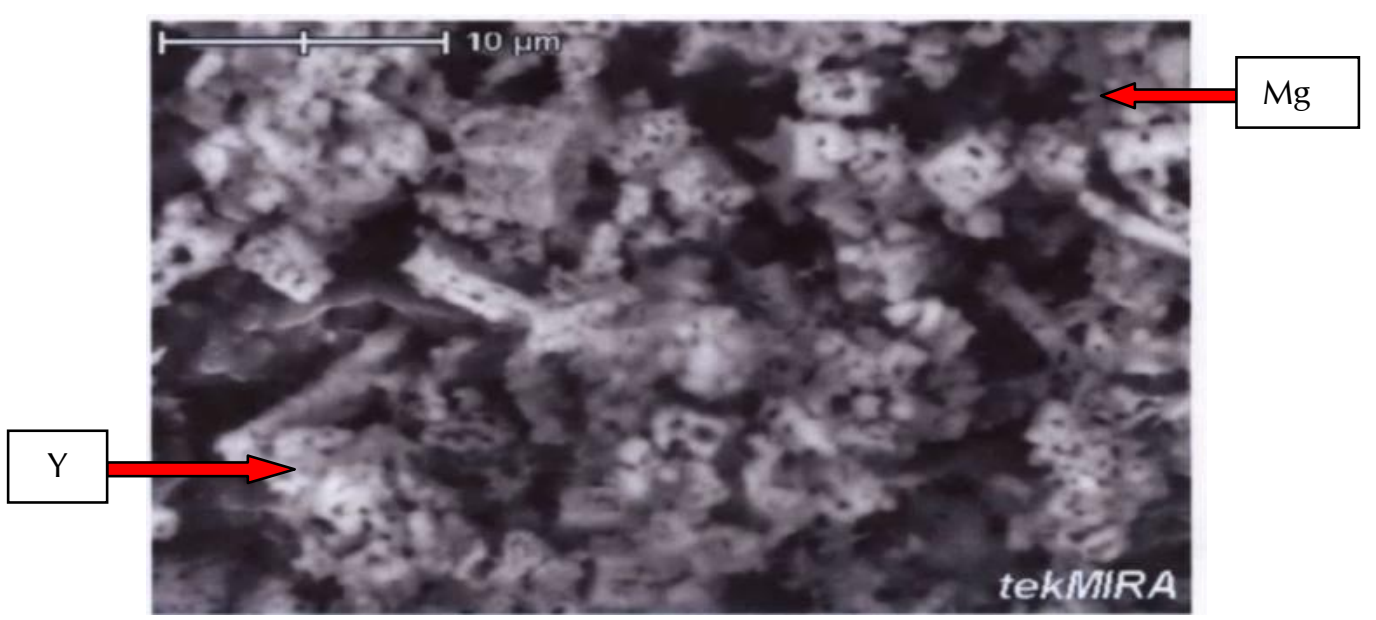

Gambar 12. Hasil analisis SEM reduksi ytrium oksida dengan reduktor Mg (1:1) dan aditif $\mathrm{NaCl}$ 


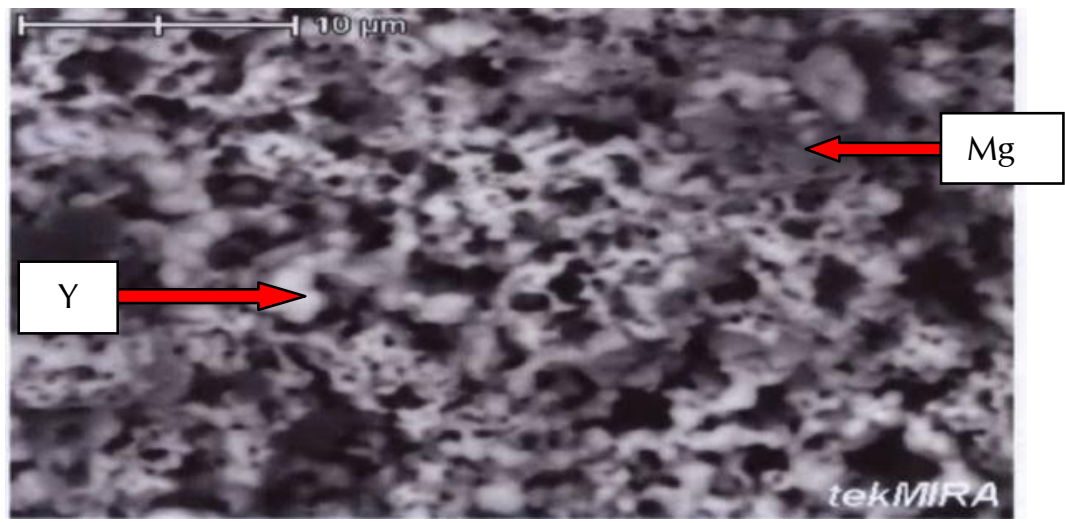

Gambar 13. Hasil analisis SEM reduksi ytrium oksida dengan reduktor $\mathrm{Mg}(1: 2)$ dan aditif $\mathrm{NaCl}$

Berdasarkan hasil dari Gambar 13 belum terbentuk logam dan hasil analisis produk terlihat porus (berpori). Kesarangan pada material ini terlihat baik. Ytrium, tantalum, alumunium dan magnesium terpetakan dengan baik. Ytrium merupakan unsur dengan kuantitas terbanyak.

Percobaan selanjutnya adalah dengan mereduksi ytrium oksida menggunakan reduktor $\mathrm{Mg}$ dan menggunakan aditif $\mathrm{NaCl}$ dan $\mathrm{CaCl}_{2}$. Hasil analisis SEM pada proses reduksi ytrium oksida dengan menggunakan reduktor $\mathrm{Mg}(1: 1)$ dan aditif $\mathrm{NaCl}+\mathrm{CaCl}_{2}$ dapat dilihat dari Gambar 14.

Berdasarkan hasil dari Gambar 14 logam ytrium belum terbentuk dan hasil analisis adalah material bersifat sarang yang sebagian berpori. Material penyusun menunjukkan struktur membulat tanggung. Terdeteksi adanya delapan unsur pada spesimen ini. Ytrium $(44,88 \%)$, osmium $(17,05 \%)$ dan rubidium $(1,28 \%)$ terpetakan dengan baik. Walaupun kuantitasnya relatif kecil dibandingkan SEM ytrium dan osmium, kemungkinan letaknya yang dekat dengan detektor SEM menyebabkan unsur ini terpetakan dengan baik seperti kedua unsur lainnya. Empat unsur yang terpetakan relatif baik adalah magnesium $(2,72 \%)$, molibdenum $(1,99 \%)$, cerium $(2,10 \%)$, disprosium $(6,07 \%)$.

Hasil analisis SEM pada proses reduksi dari ytrium oksida dengan menggunakan reduktor $\mathrm{Mg}$ (1:2) dan aditif $\mathrm{NaCl}+\mathrm{CaCl}_{2}$ dapat dilihat pada Gambar 15 .
Berdasarkan hasil dari Gambar 15 belum terbentuk logam. Terdapat tiga jenis material yang menyusun spesimen ini, yaitu material menjarum dan berlapis (abu-abu gelap) tersusun oleh kalsium. Material kedua berwarna terang, bersifat sarang dan membutir serta disusun oleh kalsium $(3,59 \%)$ dan alumunium $(2,15 \%)$. Posisi material kedua ini pada area deteksi bersifat sporadis. Material ketiga berwarna abu-abu terang tersusun oleh partikel-partikel kubistis dan disusun oleh ytrium $(4,81 \%)$, natrium, magnesium dan klor yang terpetakan dengan baik.

Hasil analisis SEM pada proses reduksi ytrium klorida dengan menggunakan reduktor $\mathrm{Mg}$ $(1: 1)$ dan aditif $\mathrm{NaCl}+\mathrm{CaCl}_{2}$ dapat dilihat pada Gambar 16.

Berdasarkan hasil dari Gambar 16 menunjukkan sudah terbentuknya logam ytrium. Spesimen disusun oleh butiran material gelap bersifat massif dan butiran material terang bersifat sarang. Kedua material menggumpal. Ytrium $(42,79 \%)$, tantalum $(1,40 \%)$, kalsium dan klor terdeteksi pada partikel-partikel sama yang umumnya berwarna terang sedangkan magnesium $(11,08 \%)$ berasosiasi dengan material gelap.

Berdasarkan hasil dari Gambar 17 tersebut tidak terbentuk logam. Hasil analisis fotomikrograf, spesimen ini dikarakterisasi oleh material berbutir mengandung kalsium dan membilah yang tersusun atas magnesium, alumunium, silikon, klor, dan ytrium. 


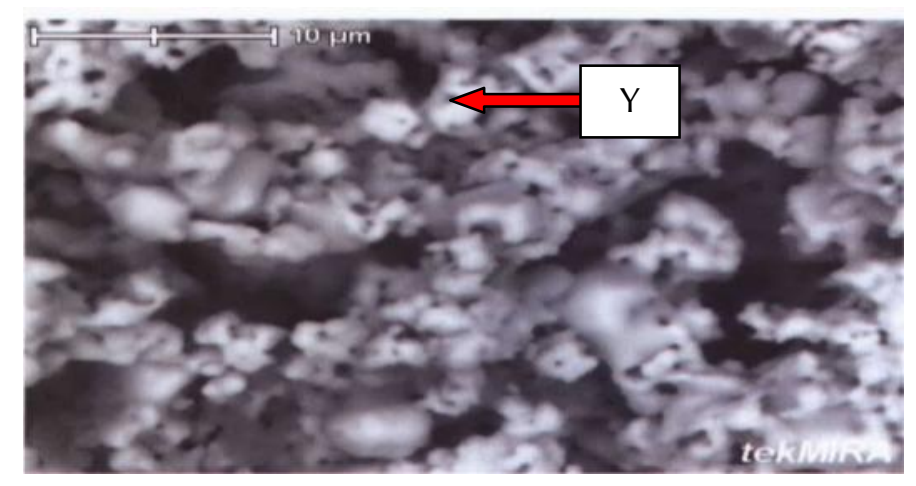

Gambar 14. Hasil analisis SEM reduksi ytrium oksida dengan reduktor $\mathrm{Mg}(1: 1)$ dan aditif $\mathrm{NaCl}+\mathrm{CaCl}_{2}$

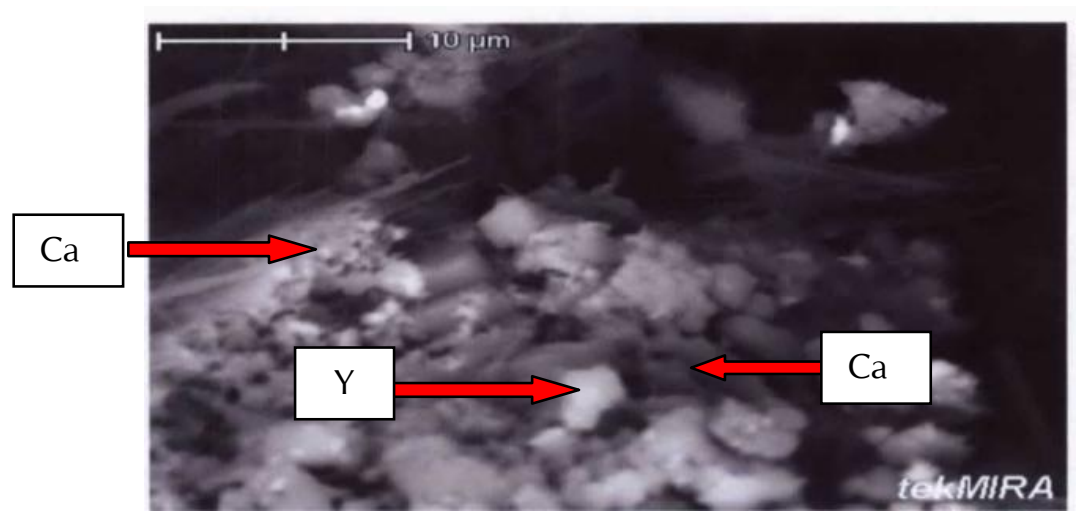

Gambar 15. Hasil analisis SEM reduksi ytrium oksida dengan reduktor $\mathrm{Mg}(1: 2)$ dan aditif $\mathrm{NaCl}+\mathrm{CaCl}_{2}$

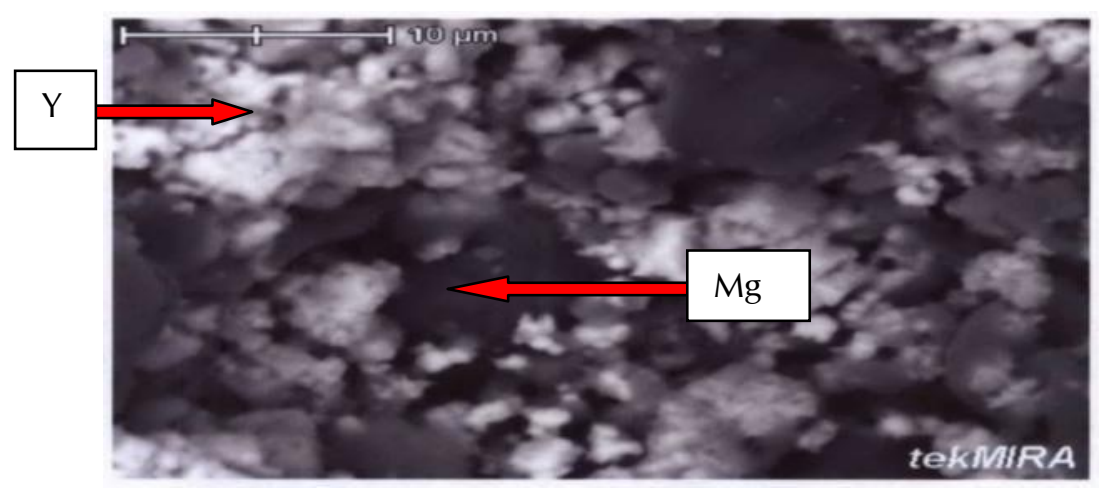

Gambar 16. Hasil analisis SEM reduksi ytrium klorida dengan reduktor $\mathrm{Mg}$ dan aditif $\mathrm{NaCl}+\mathrm{CaCl}_{2}(1: 1)$ 


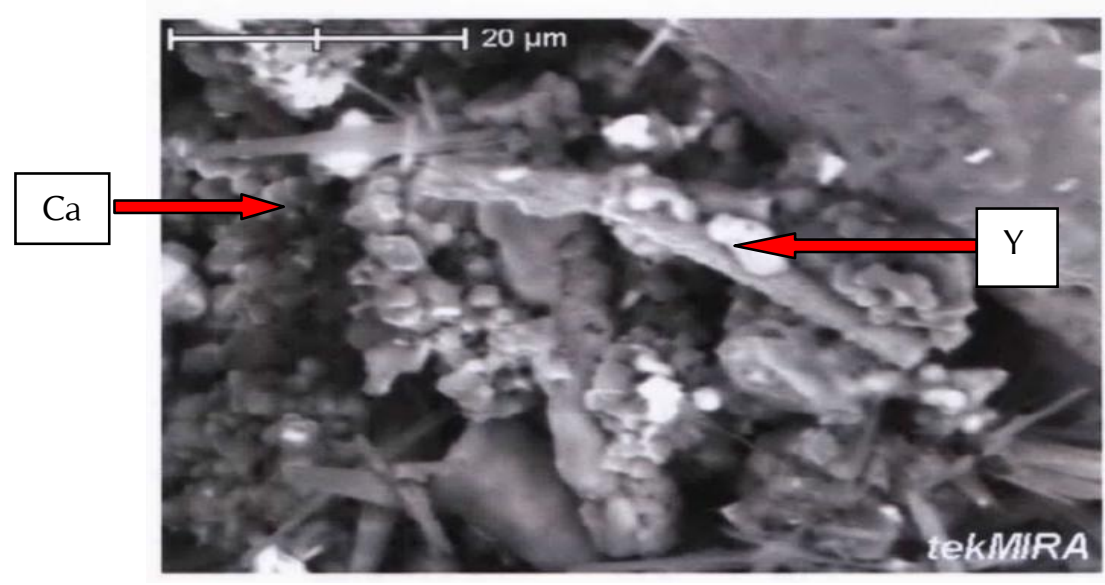

Gambar 17. Hasil analisis SEM reduksi ytrium klorida dengan reduktor $\mathrm{Mg}(1: 2)$ dan aditif $\mathrm{NaCl}+\mathrm{CaCl}_{2}$

Berdasarkan hasil-hasil percobaan di atas, logam ytrium dihasilkan dari ytrium klorida pada suhu $1200^{\circ} \mathrm{C}$, dengan reduktor $\mathrm{Mg}$ dan aditif $\mathrm{NaCl}+\mathrm{CaCl}_{2}$.

Persamaan reaksi proses reduksi yang membentuk logam ytrium adalah :

$2 \mathrm{YCl}_{3}+3 \mathrm{Mg} \rightarrow 3 \mathrm{MgCl}_{2}+2 \mathrm{Y}$

\section{KESIMPULAN DAN SARAN}

Penelitian yang dilakukan dengan mengekstraksi logam ytrium dari oksidanya melalui proses metalotermik, menghasilkan logam ytrium dengan menggunakan reduktor Ca dan $\mathrm{Mg}$ serta $\mathrm{NaCl}$ dan $\mathrm{CaCl}_{2}$ sebagai aditif. Dengan terbentuknya logam ytrium dari ytrium oksida, proses metalotermik dapat digunakan untuk pembentukan logam tanah jarang lainnya, dengan mengubah dahulu oksidanya menjadi klorida atau fluoridanya. Pembuatan logam dengan cara metalotermik ini mempunyai prospek yang baik yang mempunyai tingkat perolehan lebih dari $90 \%$.

\section{UCAPAN TERIMAKASIH}

Penulis mengucapkan terima kasih kepada PSTA-BATAN atas kerjasama penelitian khususnya dalam penyediaan bahan baku penelitian ytrium oksida. Penulis mengucapkan terima kasih pula kepada Kementerian Energi dan Sumber Daya Mineral atas pembiayaan penelitian serta rekan-rekan yang telah membantu terlaksananya penelitian ini.

\section{DAFTAR PUSTAKA}

Ames Laboratory (2016) The ames process for rare earth metals, https://www.ameslab.gov/mpc/the-amesprocess-rare-earth-metals.

Anderson, A. (2015) Investigation of the carbo chlorination process for the conversion of rare earth oxides into chlorides and measurement of their solubilty in inert molten salt. Colorado School of Mines.

Bose, D. K., Mehra, O. K. and Gupta, C. K. (1985) "Preparation of rare earth-silicon-iron alloy by metallothermic reduction," Journal of the Less Common Metals, 110(1-2), pp. 239-242. doi: 10.1016/0022-5088(85)90327-3.

Gupta, C. K. and Krishnamurthy, N. (2005) Extractive metallurgy of rare earths. Washington DC: CRC Press.

Habashi, F. (2013) "Extractive metallurgy of rare earths," Canadian Metallurgical Quarterly, 52(3), pp. 224-233. doi: 10.1179/1879139513Y.0000000081.

Koltun, P. and Tharumarajah, A. (2014) "Life cycle impact of rare earth elements," ISRN Metallurgy, 2014, pp. 1-10. doi: 10.1155/2014/907536.

Krishnamurthy, N. and Gupta, C. K. (2015) Extractive metallurgy of rare earths. 2nd ed. CRC Press. 
Kumari, A., Panda, R., Jha, M. K., Lee, J. Y., Kumar, J. R. and Kumar, V. (2015) "Thermal treatment for the separation of phosphate and recovery of rare earth metals (REMs) from Korean monazite," Journal of Industrial and Engineering Chemistry, 21, pp. 696-703. doi: 10.1016/j.jiec.2014.03.039.

Lee, M. W., Jeong, S. M., Sohn, J. M. and Lee, S. H. (2016) "A study on electrochemical reduction of rare earth oxides in molten $\mathrm{LiCl}-\mathrm{Li} 2 \mathrm{O}$ salt," Journal of Transactions of the Korean Nuclear Society, 28, p. 104.
Riedemann, T. (2011) High Purity Rare Earth Metals in Separation.

Soepriyanto, S. and Buchari (2010) "Ekstraksi logam tanah jarang di Indonesia: Permasalahan dan prospek pemanfaatannya," in Seminar nasional Pertambangan dan Metalurgi. Bandung: Institut Teknologi Bandung.

Yilmaz, S. (2007) The optimization of conditions of metallothermic reduction of rare earth preconcentrates. Middle East Technical University. 
